\title{
Preliminary evaluation of the antimicrobial activity of different Hermetia illucens larvae extracts for application as a cosmetic ingredient
}

\author{
Avaliação preliminar da actividade antimicrobiana de diferentes extractos de larvas de \\ Hermetia illucens para aplicação como ingrediente cosmético
}

\author{
Cíntia Almeida ${ }^{1}$, Daniel Murta ${ }^{1,2,3,4}$, Rui Nunes ${ }^{2}$, André Rolim Baby ${ }^{5}$, Patrícia Rijo ${ }^{1}$, Catarina Rosado ${ }^{1}$ \\ ${ }^{1}$ Lusófona University (CBIOS - Research Center for Biosciences \& Health Technologies), Lisboa, Portugal; \\ ${ }^{2}$ Ingredient Odyssey, Santarém, Portugal; ${ }^{3}$ FMV-ULHT, Lisboa, Portgual; ${ }^{4}$ CIISA-FMV-ULisboa, Lisboa, Portugal; \\ ${ }^{5}$ Faculty of Pharmaceutical Sciences, Universidade de São Paulo, São Paulo, Brazil \\ *corresponding author: catarina.rosado@ulusofona.pt
}

\begin{abstract}
The cosmetic industry is continually searching for innovative ingredients, and there is a current trend in sourcing materials of natural origin. The Hermetia illucens (Linnaeus) larvae biomass is a potential source of compounds with applicability in cosmetics due to its high lipid, protein, and polysaccharide content. High concentrations of lauric acid, also known for also having antimicrobial properties, may be obtained from the lipid fraction. Additionally, these larvae are known to have a well-developed immune system, surviving in decomposition habitats, and can be induced to produce antimicrobial peptides (AMP's). These substances could be probed as alternative preservatives in cosmetics, as consumers are often concerned with the safety of conventional preservatives, such as parabens. The present study conducted a preliminary assessment of the antimicrobial activity of the crude extracts obtained from different extraction methods and extraction solvents against four microorganisms (Gram-positive and negative bacteria and yeasts). The use of diluted extracts did not show relevant inhibition of the growth of the tested microorganisms compared to the positive controls. Further assays are foreseen to test the antimicrobial activity of compounds or fractions isolated from the crude extracts.
\end{abstract}

Keywords: Hermetia illucens extracts, bioactives, antimicrobial activity, health products ingredients

\begin{abstract}
Resumo
A indústria cosmética está constantemente a procurar ingredientes inovadores, e há uma tendência atual para o recurso a materiais de origem natural. A biomassa das larvas de Hermetia illucens (Linnaeus) é uma fonte potencial de compostos com aplicabilidade em cosméticos, devido ao seu alto teor em lípidos, proteínas e polissacáridos. Além disso, essas larvas são conhecidas por terem um sistema imunológico bem desenvolvido, sobrevivendo a habitats em decomposição, podendo ser induzidas a produzirem péptidos antimicrobianos (AMP's). Além disso, da fração lipídica é possível obter elevadas concentrações de ácido láurico, conhecido também por ter propriedades antimicrobianas. Essas substâncias podem ser sondadas como conservantes alternativos em cosméticos, uma vez que os consumidores costumam preocuparse com a segurança de conservantes convencionais, como os parabenos. O presente estudo pretendeu fazer uma avaliação preliminar da atividade antimicrobiana dos extratos brutos obtidos a partir de diferentes métodos e solventes de extração contra quatro microrganismos (bactérias Gram-positivas e negativas e leveduras). Os extratos diluídos não demostraram inibição relevante do crescimento dos microrganismos testados em comparação com os controlos positivos usados. Estão previstos ensaios adicionais para avaliar a atividade antimicrobiana de compostos ou frações isoladas a partir dos extratos brutos.
\end{abstract}

Palavras-chave: extratos de Hermetia illucens, bioativos, atividade antimicrobiana, ingredientes para produtos de saúde 


\section{Introduction}

There is a growing trend for new cosmeticproducts based in natural ingredients, as they can often improve the biocompatibility of formulations and can be produced in a sustainable way (1). The rearing of Hermetia illucens larvae seems to be a promising source of materials, as it allows the conversion of waste residues into added-value products (2-4). The $H$. illucens larvae biomass can be foreseen as an applicable source of cosmetic ingredients due to its high content in mono and polyunsaturated fatty acids (mainly lauric acid) and polysaccharides such as chitin, in addition to micronutrients such as copper, iron, selenium, zinc, and vitamins $(3,5)$. These larvae also have a well-developed immune system, are known to survive in decomposition habitats, and can be induced to produce antimicrobial peptides (AMP's). In addition, high concentrations of lauric acid, also known for having antimicrobial properties, can be obtained from the lipid fraction. These substances could be probed as alternative preservatives in cosmetics, as consumers are often concerned with the safety of conventional preservatives, such as parabens (6). In this sense, the aim of this work was to conduct a preliminary screening of the antimicrobial activity of the crude extracts obtained from $H$. illucens biomass using different extraction methods and extraction solvents.

\section{Material and Methods}

Different extraction methods were compared (decoction, microwaves, ultrasound, and maceration). The extraction methods were applied based on the types of solvents used, the pre-treatment of the biomass, and the separation method. The extraction methods were carried out in two batches, with specific modifications in order to improve the process and increase yields. The first batch consisted of the use of whole larvae in the decoction and microwave methods and ground larvae for the methods of maceration in organic solvents. In the second batch, ground larvae were used for all methods, namely, decoction, microwave, ultrasound combined with microwave, and ultrasound with organic solvents. In addition, bioactivity studies of the extracts were conducted to assess their preliminary antimicrobial properties.

\section{Introdução}

Existe uma tendência crescente de novos produtos cosméticos à base de ingredientes naturais, pois eles podem melhorar a biocompatibilidade de formulações e podem ser produzidos de maneira sustentável (1). A criação de larvas de Hermetia illucens parece ser uma fonte promissora de materiais, pois permite a conversão de resíduos em produtos de valor acrescentado (24). A biomassa de larvas de H. illucens pode ter aplicabilidade como fonte de ingredientes cosméticos, devido ao seu alto teor em ácidos gordos mono e poliinsaturados (principalmente ácido láurico) e polissacarídeos como quitina, além de micronutrientes como cobre, ferro, selénio, zinco e vitaminas $(3,5)$. Além disso, essas larvas têm um sistema imunológico bem desenvolvido e são conhecidas por sobreviverem a habitats em decomposição, podendo ser induzidas a produzir péptidos antimicrobianos (AMPs). Além disso, a partir da fração lipídica é possível obter altas concentrações de ácido láurico, conhecido por também possuir propriedades antimicrobianas. Essas substâncias podem ser sondadas como conservantes alternativos em cosméticos, uma vez que os consumidores costumam preocupar-se com a segurança de conservantes convencionais, como os parabenos (6). Nesse sentido, o objetivo deste trabalho foi conduzir uma triagem preliminar da atividade antimicrobiana de extratos brutos obtidos da biomassa de $H$. illucens usando diferentes métodos e solventes de extração.

\section{Material e Métodos}

Diferentes métodos de extração foram comparados (decocção, microondas, ultrassons e maceração). Os métodos de extração foram realizados em duas bateladas, com modificações específicas no sentido de melhorar o processe e aumentar os rendimentos. A primeira batelada consistiu no uso das larvas inteiras nos métodos decocção e microondas e, larvas trituradas para os métodos de maceração em solventes orgânicos. Já na segunda batelada, foram utilizadas as larvas já trituradas , nomeadamente, decocção, microondas, ultrasson combinado com microondas e ultrasson com solventes orgânicos. Os métodos de extração foram aplicados com base nos tipos de solventes utilizados, no pré-tratamento da biomassa e no método de separação. Além disso, foram realizados estudos de bioatividade dos extratos para avaliar as suas propriedades antimicrobianas preliminares. Os testes foram realizados em dois lotes de extração, a fim de melhorar os processos e observar melhorias nos rendimentos. 


\section{Materials}

Larvae of the H. illucens black soldier fly (LMSN) were provided by Entogreen (Santarém, Portugal). The microorganisms used in this study were obtained from the American Type Culture Collection (ATCC). They included two bacterial species (Staphylococcus aureus ATCC 25923 and Escherichia coli ATCC 25922, Grampositive and Gram-negative bacteria, respectively) and two yeasts (Saccharomyces cerevisiae ATCC 2601 and Candida albicans ATCC 10231). Microorganisms were grown at $37{ }^{\circ} \mathrm{C}$ in Muller- Hinton culture media for bacteria or Sabouraud Dextrose Agar culture medium for yeasts.

\section{Pre-treatment}

The LMSN were kept frozen at $-40^{\circ} \mathrm{C}$. Prior to performing the extractions, the larvae were washed in a steel sieve under running water, followed by two washes with distilled water. The excess water was removed with the aid of absorbent paper before weighing the wet biomass, which was approximately $218 \mathrm{~g}$.

Subsequently, the larvae were dried at $70^{\circ} \mathrm{C}$ for 48 hours in an oven (Sanyo-Drying oven) (7). The determination of dry weight was made after the temperature stabilized (30 minutes in the desiccator). For all the methods subsequently applied, $10 \mathrm{~g}$ of dried larvae sample were used. The humidity contained in the larvae was (on average) $66 \%$. Five milliliters of all the aqueous fractions (supernatants) obtained from the extraction methods were collected for lyophilisation (Labconco FreeZone $25^{\circledR}$, Labconco Corporation Kansas City, MO, USA). The dry weight of samples obtained was determined before storage for future analysis.

\section{Decoction Extraction}

In the first batch of extractions, the whole larvae were added to $100 \mathrm{~mL}$ of distilled water (at approximately $100{ }^{\circ} \mathrm{C}$, or at the beginning of the boil) and boiled for 3 minutes (8). The larvae were then ground for 3 minutes using an electric stick blender $(\mathrm{BOSCH}$, GerlingenSchillerhöhe, Germany). As previously indicated, in the second batch of extractions, the larvae were ground before the boiling in order to improve the extraction process and increase yields. After cooling, the samples were collected and centrifuged (Eppendorf Centrifuge 5804 R, Hamburg, Germany) for 7 minutes at $5000 \mathrm{rpm}$ at $4^{\circ} \mathrm{C}$. Three fractions were obtained after centrifugation: the lipid fraction at the top, characterized by a pasty and whitish consistency, the liquid supernatant, and the residual larvae pellet.

\section{Materiais}

A empresa Entogreen (Santarém, Portugal) forneceu larvas da mosca-soldado preta de $H$. illucens (LMSN). Os microrganismos utilizados neste estudo foram obtidos na American Type Culture Collection (ATCC). Estes incluíram duas espécies bacterianas (Staphylococcus aureus ATCC 25923 e Escherichia coli ATCC 25922, bactérias Gram-positivas e Gram-negativas, respeetivamente) e as leveduras Saccharomyces cerevisiae ATCC 2601 e Candida albicans ATCC 10231. Os microrganismos cresceram a $37^{\circ} \mathrm{C}$ no meio de cultura Muller-Hinton para bactérias ou meio de cultura Sabouraud Dextrose Agar para leveduras.

\section{Pré-tratamento}

As LMSN foram mantidas congeladas a $-40{ }^{\circ} \mathrm{C}$. Para realizar as extrações, as larvas foram lavadas em tamis de aço em água corrente, seguidas de duas lavagens com água destilada. $\mathrm{O}$ excesso de água foi removido com o auxílio de papel absorvente, antes da pesagem da biomassa húmida, que foi cerca de $218 \mathrm{~g}$. Posteriormente, as larvas foram secas a $70{ }^{\circ} \mathrm{C}$ por 48 horas em estufa (Estufa-SanyoDrying)-(7). A determinação do peso seco foi realizada após a temperatura estabilizada (30 minutos no exsicador). Para todos os métodos aplicados a seguir, foram utilizados $10 \mathrm{~g}$ de amostra de larvas secas. A humidade contida nas larvas foi em média $66 \%$. Foram coletados $5 \mathrm{~mL}$ de todas as frações aquosas (sobrenadante) obtidas pelos métodos de extração para liofilização (Labconco FreeZone 25®, Labconco Corporation Kansas City, MO, EUA), determinado o peso seco e armazenados para análise futura. As extrações foram realizadas em triplicado.

\section{Extração por Decocção}

No primeiro lote de extrações, as larvas inteiras foram adicionadas a $100 \mathrm{~mL}$ de água destilada (a aproximadamente $100^{\circ} \mathrm{C}$ ou no início da fervura) e fervidas por 3 minutos (8). Em seguida, as larvas foram trituradas por 3 minutos com uma trituradora $(\mathrm{BOSCH}$ Electric Stick Blender, Gerlingen-Schillerhöhe, Alemanha). No segundo lote de extrações, as larvas foram trituradas antes da fervura para melhorar o processo de extração e aumentar os rendimentos. Após o arrefecimento de todo o material, as amostras foram coletadas para centrifugação (Eppendorf Centrifuge 5804 R, Hamburgo, Alemanha) por 7 minutos a 5000 rpm a $4{ }^{\circ} \mathrm{C}$. Após a centrifugação, foram obtidas três frações: a fração lipídica no topo, caracterizada por uma consistência pastosa e esbranquiçada, o sobrenadante 
The lipid layer was collected and heated in a $35-40^{\circ} \mathrm{C}$ water bath for 15 minutes and centrifuged at $1500 \mathrm{x}$ $\mathrm{g}$ for 30 minutes at $35{ }^{\circ} \mathrm{C}$ (9). After centrifugation, a transparent lipid fraction was obtained, which was collected, weighed (averaging $530 \mathrm{mg}$ ), and stored at $-40^{\circ} \mathrm{C}$ for future analysis.

\section{Microwave Extraction}

The extraction was made using a conventional household microwave (Whirlpool Talent, Benton Harbour, MI, USA), where $100 \mathrm{~mL}$ of distilled water were added to the larvae samples and heated for 30 seconds at a power of $850 \mathrm{~W}$ (8). In the first batch of extractions, the larvae were intact (whole). In the second batch, however, the larvae were ground using an electric stick blender before the heating process in order to improve the extraction process and increase yields. The same procedures (centrifugation and separation of fractions) previously described in the decoction process were then conducted.

\section{Ultrasound extraction combined with microwave}

In effort to improve the extraction yield, in the second batch of extractions, the ground larvae mass was first subjected to a 15 minutes cold ultrasound (VWR model USC-TH, Radner, PA, USA) treatment in $100 \mathrm{~mL}$ of distilled water (8). They were then heated for 30 seconds at a power of $850 \mathrm{~W}$, followed by same centrifugation and fraction separation procedures described in the decoction and microwave process above.

\section{Extraction by maceration with organic solvents}

In the first batch, the extractions were performed by maceration using two types of organic solvents: $n$-hexane and acetone (10). For each extraction, the same volume of solvent $(100 \mathrm{~mL})$ and the procedure was followed. The larvae samples were first ground for 3 minutes with the electric stick blender. After grinding, the solvent was added and kept under low agitation for 2 hours on a shaking plate (Velp Scientifica-ARE, Usmat, Italy). The beaker was sealed with parafilm to prevent evaporation of the solvent. On cessation of agitation, a residual larvae pellet was rapidly formed by natural sedimentation and the organic supernatant was vacuum filtered using a paper filter (Whatman $\varnothing 110 \mathrm{~mm}$, Darmstadt, Germany), resulting in the separation of the organic fraction and the filtrate powder (an average of $357 \mathrm{mg}$ for extraction with $n$-hexane and $251 \mathrm{mg}$ for extraction with acetone). The addition of the same volume of solvent was repeated once more in the larvae líquido e o sedimento residual das larvas. A camada lipídica foi coletada e pré-aquecida em banho por 15 minutos, a $35-40{ }^{\circ} \mathrm{C}$, e novamente centrifugada a 1500 x g por 30 minutos a $35^{\circ} \mathrm{C}$ (9). Após a centrifugação, obteve-se uma fração lipídica transparente, que foi coletada, pesada (média de $530 \mathrm{mg}$ ) e armazenada a -40 ${ }^{\circ} \mathrm{C}$ para análises futuras.

\section{Extração por Microondas}

A extração foi realizada em microondas convencional (Whirlpool Talent, Benton Harbour, MI, USA), onde foram adicionadas às amostras de larvas $100 \mathrm{~mL}$ de água destilada e aquecidas por 30 segundos a uma potência de $850 \mathrm{~W}$ (8). No primeiro lote de extrações, as larvas estavam inteiras, mas no segundo, as larvas foram trituradas antes do processo de aquecimento para melhorar o processo de extração e aumentar os rendimentos. Em seguida, foram adotados os mesmos procedimentos descritos acima no processo de decocção: centrifugação e separação de frações.

\section{Extração por ultrassons combinada com microondas}

No esforço de melhorar o rendimento da extração, no segundo lote de extrações em que as larvas foram utilizadas já trituradas, a massa de larvas foi primeiramente submetida a um tratamento de ultra-som (VWR, limpador ultrassónico USC-TH, Radner, PA, USA), frio de 15 minutos em $100 \mathrm{~mL}$ de água destilada (8). Em seguida, foram aquecidos por 30 segundos a uma potência de 850 W. Foram adotados os mesmos procedimentos descritos acima no processo de decocção e microondas: centrifugação e separação de frações.

\section{Extração por maceração com solventes orgânicos}

No primeiro lote, as extrações foram realizadas por maceração utilizando dois tipos de solventes: $n$-hexano e acetona (10). Para cada extração, foram utilizados o mesmo volume de solvente $(100 \mathrm{~mL})$ e as mesmas etapas do procedimento. Inicialmente, as amostras de larvas foram trituradas por 3 minutos com a trituradora. Após a trituração, o solvente foi adicionado e mantido sob baixa agitação por 2 horas em placa de agitação (Velp Scientifica-ARE, Usmat, Itália). O copo foi levemente selado com parafilme para evitar a evaporação do solvente. Após a cessação da agitação, um sedimento residual de larvas foi rapidamente formado por sedimentação natural e, o sobrenadante orgânico foi filtrado a vácuo usando um filtro de papel (Whatman ø $110 \mathrm{~mm}$, Darmstadt, Alemanha), resultando na separação da fração orgânica 
pellet. From the resulting total volume, the solvent was removed on a rotary vacuum evaporator $\left(\mathrm{IKA}^{\circledR}\right.$, Werke RV06-ML, Staufen, Germany) at a temperature of 50 ${ }^{\circ} \mathrm{C}$. The extract obtained was collected, weighed, and stored at $-40{ }^{\circ} \mathrm{C}$ for future analysis. The material that was retained in the filter was also weighed and stored.

\section{Ultrasonic extraction with organic solvents}

In the second batch of extractions, a 15 minutes ultrasound treatment was applied to the ground larvae using each of the solvents ( $n$-hexane and acetone) prior to the timed agitation. For each extraction, the same volume of solvent $(100 \mathrm{~mL})$ was used. Subsequently, the same procedures described in the previous section were followed.

\section{Antimicrobial activity evaluation}

For each extraction method, the lipid fractions of the extracts were collected and antimicrobial activities assays were conducted. The antimicrobial activity was performed using the well diffusion method $(11,12)$. The extracts were dissolved in $n$-hexane, applied at a concentration of $10 \mathrm{mg} \cdot \mathrm{mL}^{-1}$.

Briefly, the antimicrobial activity test was performed in Petri dishes with the appropriate medium inoculated with $0.1 \mathrm{~mL}$ of a microbial cell suspension matching a $0.5 \mathrm{McFarland}$ standard solution. The suspension was uniformly spread using a sterile swab over the surface of the medium. Wells of approximately $5 \mathrm{~mm}$ in diameter were made in the agar plates with a sterile glass Pasteur pipette and $50 \mu \mathrm{L}$ of each extract was added into the well. $N$-hexane was used as a negative control, while vancomycin, norfloxacin and nystatin $\left(1 \mathrm{mg} \cdot \mathrm{mL}^{-1}\right)$ were used as positive controls for Gram-positive, Gram-negative bacteria and yeast, respectively. The plates were then incubated at $37{ }^{\circ} \mathrm{C}$ for 24 hours. The antimicrobial activity was assayed by measuring the diameter of the inhibition zone formed around the wells. Each assay was performed in triplicate. e do pó do filtrado (uma média de $357 \mathrm{mg}$ para extração com $n$-hexano e $251 \mathrm{mg}$ para extração com acetona). A adição do mesmo volume de solvente foi repetida mais uma vez sobre o sedimento das larvas. Do volume total resultante, o solvente foi removido utilizando um evaporador rotativo a vácuo (IKA ${ }^{\circledR}$, Werke RV06-ML, Staufen, Alemanha) a uma temperatura de $50^{\circ} \mathrm{C}$. O extrato obtido foi coletado, pesado e armazenado a -40 ${ }^{\circ} \mathrm{C}$ para análises futuras. $\mathrm{O}$ material que foi retido no filtro também foi pesado e armazenado.

\section{Extração por ultrassons com solventes orgânicos}

No segundo lote de extrações, decidiu-se aplicar 15 minutos de ultrassons às larvas trituradas usando os dois tipos de solventes: $n$-hexano e acetona. Para cada extração, o mesmo volume de solvente. Posteriormente, foram seguidos os mesmos procedimentos descritos na secção anterior.

\section{Avaliação da atividade antimicrobiana}

Após cada método de extração, as frações lipídicas dos extratos foram coletadas e os ensaios de atividades antimicrobianas foram realizados. A atividade antimicrobiana foi realizada pelo método de difusão em poços $(11,12)$. Os extratos obtidos foram dissolvidos em $n$-hexano, aplicados a numa concentração de $10 \mathrm{mg} \cdot \mathrm{mL}^{-1}$. Resumidamente, o teste de atividade antimicrobiana foi realizado em placas de Petri com o meio apropriado inoculado com $0,1 \mathrm{~mL}$ de uma suspensão de células microbianas combinando com uma solução padrão de $0,5 \mathrm{McFarland}$. A suspensão foi espalhada uniformemente usando uma zaragatoa estéril sobre a superfície do meio. Os poços de aproximadamente $5 \mathrm{~mm}$ de diâmetro foram feitos nas placas de ágar com uma pipeta Pasteur de vidro estéril, onde $50 \mu \mathrm{L}$ de cada extrato previamente diluído (10 $\mathrm{mg} \cdot \mathrm{mL}^{-1}$ ) foram adicionados ao poço. $\mathrm{O} N$-hexano foi usado como controle negativo, enquanto a vancomicina, a norfloxacina e a nistatina $\left(1 \mathrm{mg} \cdot \mathrm{mL}^{-1}\right)$ foram usadas como controle positivo para bactérias Gram-positivas, Gram-negativas e leveduras, respetivamente. As placas foram incubadas a $37{ }^{\circ} \mathrm{C}$ por 24 horas. A atividade antimicrobiana foi testada medindo o 243 diâmetro da zona de inibição formada ao redor dos poços. Cada ensaio foi realizado em triplicado. 
Table 1 - Antibacterial activity determined with antibiotics used as a positive control. Antibiotic inhibition zone including the diameter of the well $(5 \mathrm{~mm})$ : a - vancomycin $\left(1 \mathrm{mg} \cdot \mathrm{mL}^{-1}\right)$; b - norfloxacin $\left(1 \mathrm{mg} \cdot \mathrm{mL}^{-1}\right)$; $\mathrm{c}-$ nystatin $\left(1 \mathrm{mg} \cdot \mathrm{mL}^{-1}\right)$. Extracts were identified as DEC - Decoction; MICR - microwave; UMICR - ultrasound + microwave; HEX - n-hexane; ACET - acetone.

Tabela 1 - Determinação da atividade antibacteriana utilizando antibióticos como controle positivo. Zona de inibição de antibióticos, incluindo o diâmetro do poço $(5 \mathrm{~mm})$ : a - vancomicina $\left(1 \mathrm{mg} \cdot \mathrm{mL}^{-1}\right)$; b - norfloxacina $\left(1 \mathrm{mg} \cdot \mathrm{mL}^{-1}\right)$; $\mathrm{c}$ - nistatina $\left(1 \mathrm{mg} \cdot \mathrm{mL}^{-1}\right)$. Os extratos foram identificados como DEC - Decocção; MICR microondas; UMICR - ultrassons + microondas; HEX - n-hexano; ACET - acetona.

\begin{tabular}{|l|c|c|c|c|c|c|c|}
\hline \multirow{3}{*}{ Strain / Estirpe } & \multicolumn{7}{|c|}{ Inhibition Zone / Zona de inibição (mm) } \\
\cline { 2 - 9 } & $\begin{array}{c}\text { Antibiotics / } \\
\text { Antibióticos }\end{array}$ & $\begin{array}{c}\text { n-Hexane / } \\
\text { n-Hexano }\end{array}$ & DEC & MICR & UMICR & HEX & ACET \\
\hline S. aureus & $20.0^{\mathrm{a}}$ & 5 & 5 & 5 & 5 & 5 & 5 \\
\hline E. coli & $33.7^{\mathrm{b}}$ & 5 & 5 & 5 & 5 & 5 & 5 \\
\hline C. albicans & $19.7^{\mathrm{c}}$ & 5 & 5 & 5 & 5 & 5 & 5 \\
\hline S. cerevisae & $26.7^{\mathrm{c}}$ & 5 & 5 & 5 & 5 & 5 & 5 \\
\hline
\end{tabular}

\section{Results}

The present work aimed to conduct a preliminary assessment of the antimicrobial properties of the lipid fraction of crude $H$. illucens extracts obtained using different extraction methods and solvents. Among the bioactive compounds present in the biomass of $H$. illucens, fatty acids were selected as being of interest, and extracts rich in these substances, especially in lauric acid, were expected to be obtained.

The antimicrobial activity of the extracts was conducted by determining their ability to inhibit the growth of Gram-positive bacteria $S$. aureus and Gram-negative $E$. coli, as well as two yeasts $C$. albicans and $S$. cerevisiae using a well diffusion assay.

The results of the preliminary test of different extracts for antimicrobial activity are shown in Table 1 and Figure 1. It was concluded that the extracts at 10 $\mathrm{mg} \cdot \mathrm{mL}^{-1}$ were not active for the microorganisms tested in this study, as all extracts presented zones of inhibition of $5 \mathrm{~mm}$, equal to that obtained with the negative $n$-hexane control. It can also be noted that these results were obtained both in extracts obtained with aqueous and organic solvents. In addition, no differences in antimicrobial were found between the extracts prepared by maceration, decoction, ultrasound, and microwave.

\section{Resultados}

O presente trabalho teve como objectivo fazer uma avaliação prévia das propriedades antimicrobianas da fração lipídica dos extratos. Dentro dos compostos bioativos presentes na biomassa de H. illucens foram selecionados os ácidos gordos como tendo interesse, havendo a expectativa de conseguir, através de diferentes metodologias e solventes, extratos ricos nestas substâncias, sobretudo em ácido láurico.

A atividade antimicrobiana dos extratos foi realizada determinando a sua capacidade de inibir o crescimento das bactérias Gram-positivas $S$. aureus e Gramnegativas $E$. coli, além de duas leveduras $C$. albicans e $S$. cerevisiae usando o método de difusão do poço.

Os resultados do teste preliminar de diferentes extratos para atividade antimicrobiana são apresentados na Tabela 1 e Figura 1. Concluiu-se que os extratos a 10 $\mathrm{mg} \cdot \mathrm{mL}^{-1}$ não foram ativos para os microrganismos testados neste estudo, uma vez que todos os extratos apresentaram zonas de inibição de $5 \mathrm{~mm}$, iguais às obtidas com o controle $n$-hexano negativo, referente ao tamanho do poço. Pode ser também salientado que estes resultados foram obtidos tanto nos extratos obtidos com solventes aquosos, quer orgânicos. Adicionalmente, não foram encontradas diferenças entre os extratos preparados por maceração, decocção, ultrassons e micro-ondas. 


\section{Discussion}

As mentioned previously, antimicrobial properties have been attributed to lauric acid (C12:0). This is one of the predominant fatty acids in the lipid fraction obtained from the biomass of $H$. illucens larvae, which has a high content of medium chain fatty acids (C12:0 and C14:0) $(6,13)$. In the work conducted by Anzaku et al . (14), lauric acid exhibited high antimicrobial activity against both Gram-negative and Gram-positive bacteria. The results of this study showed that the zones of inhibition were reduced with decreasing concentration $(14,15)$.

\section{Discussão}

Como mencionado anteriormente, é sabido que o ácido láurico possui propriedades antimicrobianas. Uma das características marcantes da fração lipídica obtida a partir da biomassa das larvas de H. illucens, é o alto conteúdo de ácidos gordos de cadeia média (C12:0 e C14:0), principalmente pela presença de ácido láurico (C12:0) $(6,13)$. Em estudos realizados por Anzaku et al. (14), o ácido láurico exibiu atividade antimicrobiana para bactérias Gram-negativas e Gram-positivas. Este estudo permitiu também concluir que as zonas de inibição diminuíram à medida que a concentração da diluição diminuł $(14,15)$.
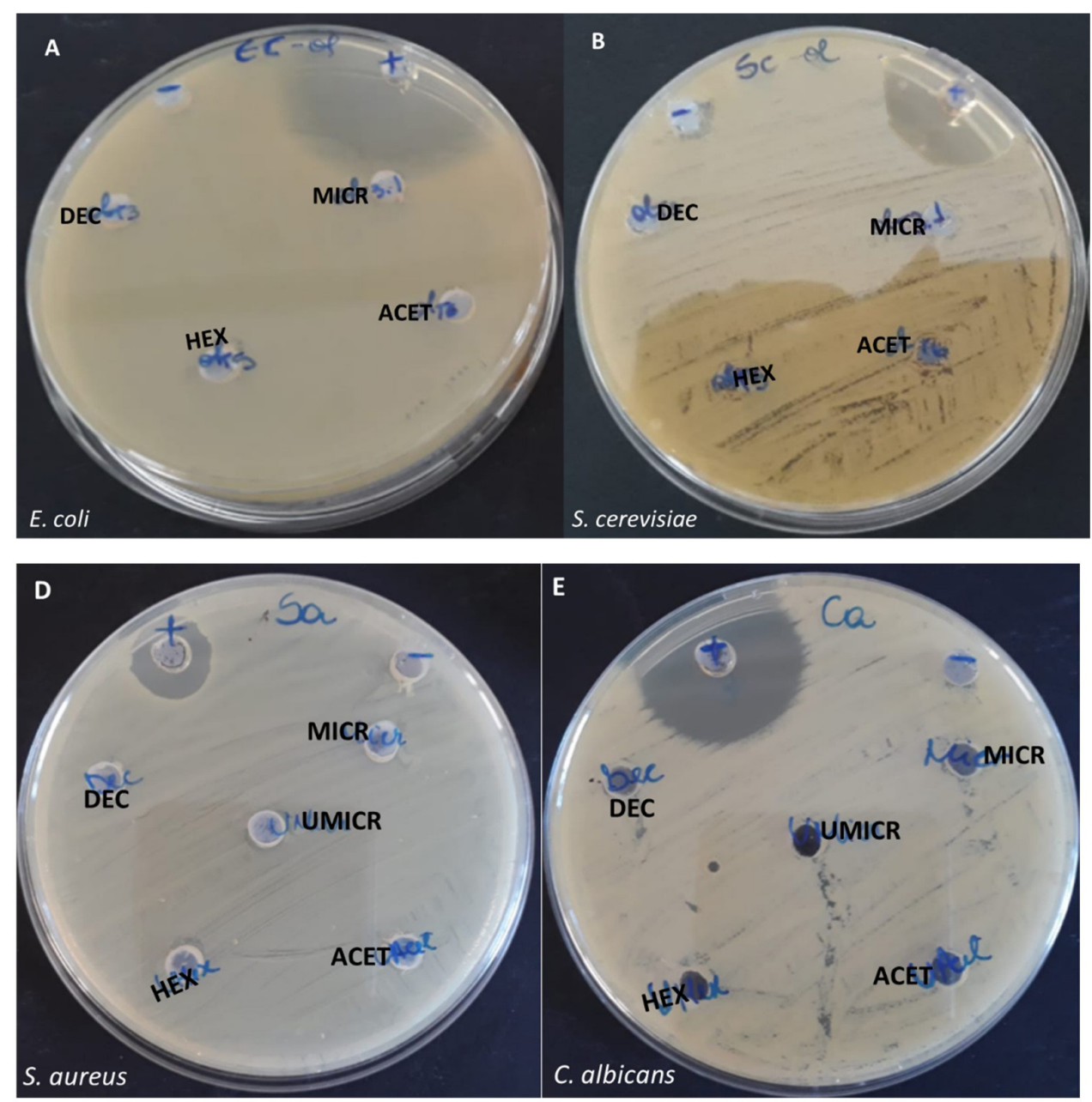

Figure 1 - Tests for antimicrobial activity. In A and B, tests with extracts from the first batch of extractions with bacteria $E$. coli and yeast $S$. cerevisiae; $\mathrm{C}$ and D - tests with extracts from the second batch of extractions with bacteria $S$. aureus and yeast $C$. albicans. Extracts were identified as DEC - Decoction; MICR - microwave; UMICR - ultrasound + microwave; HEX - n-hexane; ACET - acetone.

Figura 1 - Testes para atividade antimicrobiana. Em A e B, testes com extratos do primeiro lote de extrações com a bactéria $E$. coli e a levedura $S$. cerevisiae; C e D - testes com extratos do segundo lote de extrações com a bactéria $S$. aureus e a levedura $C$. albicans. Os extratos foram identificados como DEC - Decocção; MICR - microondas; UMICR - ultrassons + microondas; HEX - n-hexano; ACET - acetona 
It is suggested that further studies should be performed in which lipid fractions of crude extracts (without dilution) are initially tested for antimicrobial evaluation, since they have been reported to have high concentrations of lauric acid (6). In addition, testing the minimum inhibitory concentration (MIC) of the extracts against each microorganism would be important to determine the concentration that will provide antimicrobial activity. Finally, a strategy to isolate the compounds with putative antimicrobial activity from the extracts should also be developed.

\section{Conclusion}

H. illucens larvae extracts are rich in bioactive substances and can play an important role in the development of innovative ingredients. The larvae lipids, proteins and chitin content have a vast application, and these substances are worth considering as high value co-products. In the present study, different extractions methods and extraction solvents were used with the aim of obtaining bioactive compounds from $H$. illucens biomass. However, the previously tested extracts, diluted in hexane, did not show a relevant inhibition of the growth of the tested microorganisms in comparison with the positive controls. Further assays are foreseen to test the antimicrobial activity of compounds or fractions isolated from the crude extracts produced.

\section{Author Contributions Statement}

PR, CA and CR conceptualization and study design; CA and PR experimental implementation; CA, PR and CR data analysis; CA illustrations; CA, DM, $\mathrm{RN}, \mathrm{PR}$ and $\mathrm{CR}$ drafting editing and reviewing

\section{Conflict of Interest}

The senior editor co-authoring this manuscript had no participation in the review nor in the decision process.

All authors have declared there were no financial and/or personal relationships that may present a potential conflict of interest.
Face aos resultados obtidos, sugere-se que novos estudos sejam realizados onde as frações lipídicas dos extratos brutos (sem diluição prévia) sejam testadas inicialmente para avaliação antimicrobiana, uma vez que possuem alta concentração de ácido láurico (6). Adicionalmente, seria importante testar a concentração inibitória mínima (CIM) dos extratos contra cada microrganismo, a fim de verificar até que concentração permanecerá a atividade antimicrobiana. Finalmente, deverá ser também tentada uma estratégia em que os compostos com putativa atividade microbiana são isolados dos extratos.

\section{Conclusão}

Os extratos de larvas de $H$. illucens são ricos em substâncias bioativas e, portanto, podem desempenhar um papel importante no desenvolvimento de ingredientes inovadores. O teor de lípidos, proteínas e quitina das larvas tem uma vasta aplicação e podem considerar-se essas substâncias como co-produtos de alto valor. Neste estudo, diferentes métodos e solventes de extração foram testados na biomassa de $H$. illucens com o objetivo de obter compostos bioativos. No entanto, o uso dos extratos previamente dissolvidos em hexano para avaliação da atividade antimicrobiana não demostrou inibição relevante do crescimento dos microrganismos testados em comparação com os controlos positivos usados. Estão previstos ensaios adicionais para avaliar a atividade antimicrobiana de compostos ou frações isoladas a partir dos extratos brutos produzidos.

\section{Declaração sobre as contribuições do autor}

PR, CA e CR, Conceptualização e desenho de estudos; CA e PR implementação experimental; CA, PR e CR Análise de dados; CA ilustrações; $\mathrm{CA}, \mathrm{DM}, \mathrm{RN}, \mathrm{PR}$ e CR, edição e revisão da redação

\section{Conflito de Interesses}

O editor senior envolvido na autoria deste manuscrito não teve qualquer participação no processo de revisão ou de decisão.

Todos os autores declararam não haver relações financeiras e/ou pessoais que possam representar um potencial conflito de interesses. 


\section{Funding}

This work was financially supported by Fundação para a Ciência e a Tecnologia (FCT, Portugal), through projects UID/DTP/04567/2019 and UIDB/04567/2020 and by the research grant attributed to C.A. UID/ DTP/04567/2019-CBIOS/BI3. Additionally, the authors would like to acknowledge funding of the project ENTOVALOR (POCI-01-0247-FEDER-017675: ENTOVALOR - Insects as an opportunity in residues valorisation (2016-2019)).

\section{Financiamento}

Este trabalho foi financiado pela Fundação para a Ciência e a Tecnologia (FCT, Portugal), através dos projectos UID/DTP/04567/2019 e UIDB/04567/2020 e pela bolsa de investigação atribuída a Cíntia Almeida UID/DTP/04567/2019-CBIOS/BI3. Os autores também gostariam de agradecer o financiamento do projecto ENTOVALOR (POCI-01-0247-FEDER-017675: ENTOVALOR - Insects as an opportunity in residues valorisation (2016-2019)). 


\section{References / Referências}

1. Aranaz I, Acosta N, Civera C, Elorza B, Mingo J, Castro C, Gandía M, Heras Caballero A. (2018) Cosmetics and Cosmeceutical Applications of Chitin, Chitosan and Their Derivatives. Polymers, 10(2):213.

2. Verheyen GR, Ooms T, Vogels L, Vreysen S, Bovy A, Van Miert S, Meersman F. (2018) Insects as an Alternative Source for the Production of Fats for Cosmetics. J Cosmet Sci, 69(3):187-202.

3. van Huis A, Van Itterbeeck J, Klunder H, Mertens E, Halloran A, Muir G, Vantomme P. (2013) Edible insects: future prospects for food and feed security. FOA Forestry Paper 171, Food And Agriculture Organization of the United Nations. FAO and Wageningen UR (ed.)

4. Tomberlin JK, Sheppard DC, Joyce JA (2002) Selected Life-History Traits of Black Soldier Flies (Diptera: Stratiomyidae) Reared on Three Artificial Diets, Ann. Entomol. Soc. Am. 95(3):379-386.

5. Rumpold BA and Schlüter OK. (2013) Nutritional composition and safety aspects of edible insects. Mol. Nutr. Food Res. 57(5):802823.

6. Ushakova NA, Brodskii ES, Kovalenko AA, Bastrakov AI, Kozlova AA, Pavlov DS. (2016) Characteristics of lipid fractions of larvae of the black soldier fly Hermetia illucens. Dokl Biochem Biophys. 468(1):209-12.

7. Newton RDL, Sheppard C, Watson DW, Burtle G (2005) Using the black soldier fly, Hermetia illucens, as a value-added tool for the management of swine manure. Report of the Animal and Poultry Waste Management Center, North Carolina State University. Raleigh (US): North Carolina State University.

8. Rijo P, Falé PL, Serralheiro ML, Simões MF, Gomes A, Reis C. (2014) Optimization of medicinal plant extraction methods and their encapsulation through extrusion technology', Meas. J. Int. Meas. Confed.58:249-55.

9. Tzompa Sosa DA, Yi L, van Valenberg HJF, van Boekel MAJS, Lakemond CMM (2014) Insect lipid profile: Aqueous versus organic solvent-based extraction methods. Food Res. Int. 62:1087-94

10. Brum AAS, de Arruda LF, Regitano-d'Arce MAB (2009) Métodos de extração e qualidade da fração lipídica de matérias-primas de origem vegetal e animal. Química Nova. 32:849-54.

11. Rijo P, Batista M, Matos M, Rocha H, Jesus S, Simões M. (2012) Screening of antioxidant and antimicrobial activities on Plectranthus spp. extracts, Biomed. Biopharm. Res. 9(2):225-35.

12. Epole Ntungwe N, Marçalo J, Garcia C, Reis C, Teodósio C, Oliveira C, Oliveira C, Roberto A, Rijo P. (2017) Biological activity screening of seven Plectranthus species Biomed. Biopharm. Res. 14(1):95-108

13. Rabani V, Cheatsazan H, Davani S. (2019) Proteomics and Lipidomics of Black Soldier Fly (Diptera: Stratiomyidae) and Blow Fly (Diptera: Calliphoridae) Larvae. J. Insect Sci., 19(3):29.

14. Anzaku AA, Akyala JI, Juliet A, Obianuju EC. (2017) Antibacterial Activity of Lauric Acid on Some Selected Clinical Isolates. Ann. Clin. Lab. Res. 7:1-5.

15. Nakatsuji T, Kao MC, Fang JY, Zouboulis CC, Zhang L, Gallo RL, Huang CM. (2009) Antimicrobial property of lauric acid against propionibacterium acnes: Its therapeutic potential for inflammatory acne vulgaris. J. Invest. Dermatol. 129(10):2480-2488. 